\title{
Effects of soil-engineering properties on the failure mode of shallow landslides
}

\section{Jonathan Peter McKenna, Paul Michael Santi, Xavier Amblard \& Jacquelyn Negri}

\section{Landslides}

Journal of the International Consortium on Landslides

ISSN 1612-510X

Landslides

DOI 10.1007/s10346-011-0295-3

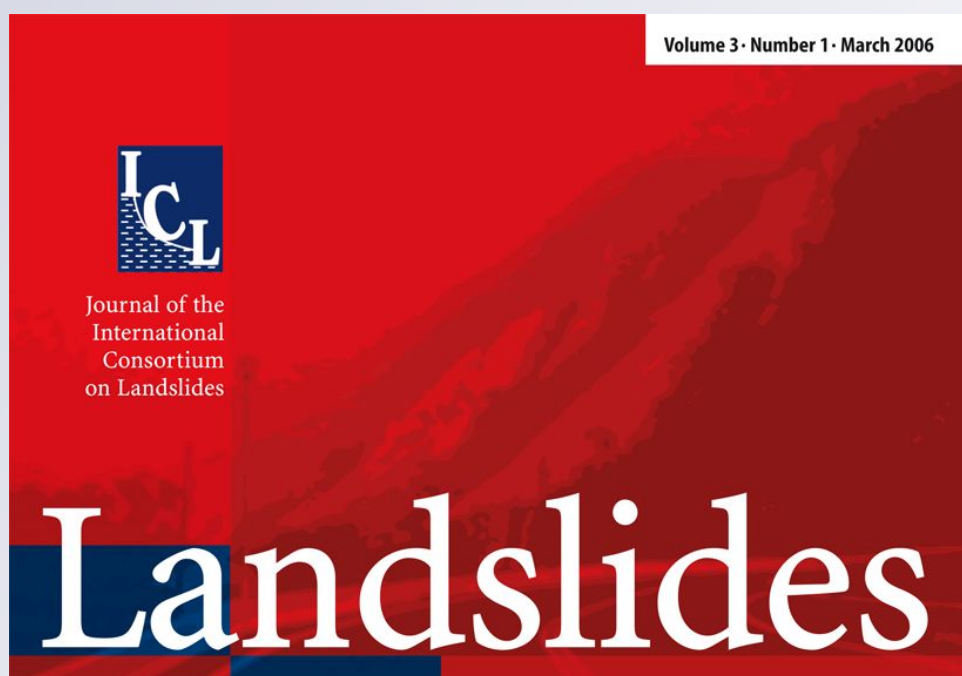

Online First
Immediately Online

Springer 
Your article is protected by copyright and all rights are held exclusively by SpringerVerlag (outside the USA). This e-offprint is for personal use only and shall not be selfarchived in electronic repositories. If you wish to self-archive your work, please use the accepted author's version for posting to your own website or your institution's repository. You may further deposit the accepted author's version on a funder's repository at a funder's request, provided it is not made publicly available until 12 months after publication. 
Landslides

DOI 10.1007/s10346-011-0295-3

Received: 25 April 2011

Accepted: 24 August 2011 ๑ Springer-Verlag (outside the USA) 2011 mode of shallow landslides
Jonathan Peter McKenna · Paul Michael Santi · Xavier Amblard · Jacquelyn Negri Effects of soil-engineering properties on the failure on physical properties of the soil (Wang and Sassa 2003), effective normal stress, and the stress history of the material (e.g., Schofield and Wroth 1968; Atkinson 1993). Saturated soils with porosities greater than the critical-state value can contract upon shearing, reducing effective pore space and potentially causing pore pressures to temporarily increase, reducing frictional strength, and accelerating deformation and movement which can transform some landslides into rapidly moving liquefied flows (e.g., Casagrande 1976; Sassa 1984; Ellen and Fleming 1987; Iverson and LaHusen 1989; Anderson and Reimer 1995; Iverson 1997, 2005; Fuchu et al. 1999; Iverson et al. 2000; Wang and Sassa 2003; Moriwaki et al. 2004). Conversely, soils with initial porosities less than the critical-state values will dilate upon shearing as individual grains ride up and over adjacent grains, increasing effective pore volume, potentially reducing pore-water pressures and resulting in increased normal stress and frictional strength at grain contacts, thereby retarding deformation and movement (Ellen and Fleming 1987; Iverson et al. 1997, 2000; Moore and Iverson 2002; Iverson 2005).

The likelihood for a landslide to mobilize into a flow has been assessed in several ways. Johnson and Rodine (1984) defined a mobility index $(M)$, which is a ratio of water content at field capacity to water content of the soil necessary to flow in a specific channel. Johnson and Rodine (1984) used $M$ to identify soils prone to mobilization. They found that $M<0.9$ did not produce flows, while flows were more likely to occur when $M>1$. Ellen and Fleming (1987) introduced the approximate mobility index (AMI) as a ratio of in situ saturated water content to the water content at the liquid limit. AMI> 1 identifies soils with initial capacity to hold more water than their liquid limits. Soils with AMI $<1$ must dilate in order to increase initial water capacity beyond the liquid limit.

Theoretical analyses, experiments, and laboratory tests suggest that the geotechnical properties controlling whether a precipitationinduced landslide will slide episodically or mobilize into a flow are initial porosity (Eckersley 1990; Iverson et al. 2000), permeability (Iverson and LaHusen 1989; Day 1994; Iverson et al. 1998), and grainsize distribution (Ellen and Fleming 1987; Kramer 1988; Wang and Sassa 2003; Gabet and Mudd 2006). Morphological features such as channel gradient, angle of entry of failure into the channel, volume of in-channel stored sediment, and initial failure volume have also been shown to influence mobilization and travel distances of debris flows (Benda and Dunne 1987; Benda and Cundy 1990; Rood 1990; Bovis and Dagg 1992; Brayshaw and Hassan 2009). Numerous researchers have also demonstrated that hollows are important sources for debris flows because concave topography routes groundwater into convergent flow (Smith and Hart 1982; Ellen and Fleming 1987; Reneau and Dietrich 1987).

Previous work supports the hypothesis that landslide-induced flows and slides depend on the contractive and dilative nature of source soils. Consequently, the division between the two failure modes is the critical-state porosity. Since dilation and contraction are mechanical processes, we hypothesize that the critical-state porosity can be predicted as a function of the material properties. In this paper, are rearranged and approach specific, critical-state porositie (alternative measures include void ratio and density) which depend 
we test this hypothesis by evaluating material properties of soils in landslide prone areas of Oregon and Colorado. The material properties of interest include initial dry density $\left(\rho_{\mathrm{d}}\left[\mathrm{g} / \mathrm{cm}^{3}\right]\right)$, saturated hydraulic conductivity $\left(k_{\text {sat }}[\mathrm{cm} / \mathrm{s}]\right)$, Atterberg Limits, and grain-size distribution. We also test the applicability of AMI for predicting landslide failure mode.

\section{Study areas}

We chose 11 field areas (Figs. 1 and 2) that had shallow slides and flows in close proximity to one another. The initial conditions prior to the occurrence of landslides at the various field areas were mixed (Table 1), but the majority of the field areas were deforested by clear-cut logging. Nine field areas (Big Creek (BC), Camp Creek (CC), Charlotte Creek (CHC), Island View (IV), Island View B (IVB), Maupin Road (MR), Powder House (PH), Sulphur Creek (SC), and Tyee Mountain (TM)) are located in the Oregon Coast Range; one is located in the Portland Hills, Oregon (Forest Park (FP), Fig. 1), and a final site is located near Durango, Colorado (Florida River (FR)) in the San Juan Mountains (Fig. 2). Because the critical-state porosity depends on the physical properties of the soil, the effective normal stress, and the stress history of the material, we chose study areas containing both shallow (maximum depth $<5 \mathrm{~m}$, median failure depth $0.8 \mathrm{~m}$ ) slides and flows that failed under similar normal-stress loads (median normal stress $11 \mathrm{kPa}$ for both slides and flows) and within material types that have similar stress history. All the landslides occur within colluvial soil or within soil derived from weathered bedrock for which we assume the original bedrock stress conditions have been severely altered or completely destroyed. Small landslides $\left(65 \mathrm{~m}^{3}\right.$ median volume) were investigated to minimize the natural spatial variability of the material properties that may be associated with large landslides.

\section{Geology}

Field areas in the Oregon Coast Range (Fig. 1) were all located within soils formed on the Tyee Formation, with the exception of CC which is located in the Elkton Formation (Baldwin 1961). The Tyee Formation $(1,500-1600 \mathrm{~m})$ is middle Eocene in age and generally consists of thick to very thick cliff forming, well-indurated, micaceous, arkosic, sandstone, and thin-bedded siltstone (Niem and Niem 1990). The Elkton formation is also middle Eocene in

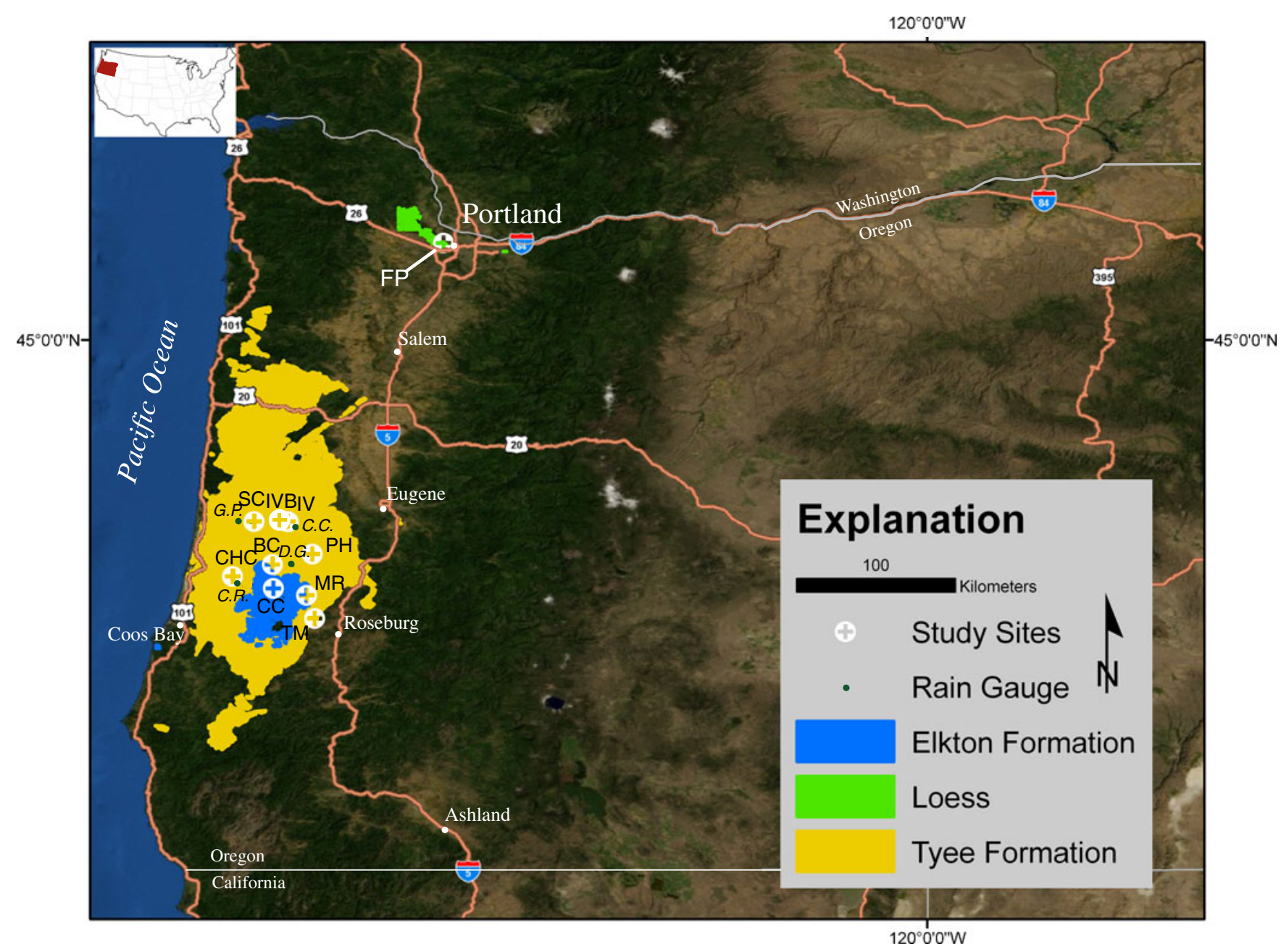

Fig. 1 General geology of field study areas in Oregon. Field areas include Big Creek $(B C)$, Camp Creek $(C C)$, Charlotte Creek $(C H C)$, Island View (IV), Island View B $(I V B)$, Maupin Road $(M R)$, Powder House $(P H)$, Sulphur Creek $(S C)$, Tyee
Mountain (TM), and Forest Park (FP). Rain gauges include Charlotte Ridge (C.R.), Goodwin Peak (G.P.), Clay Creek (C.C.), and Devils Graveyard (D.G.) 


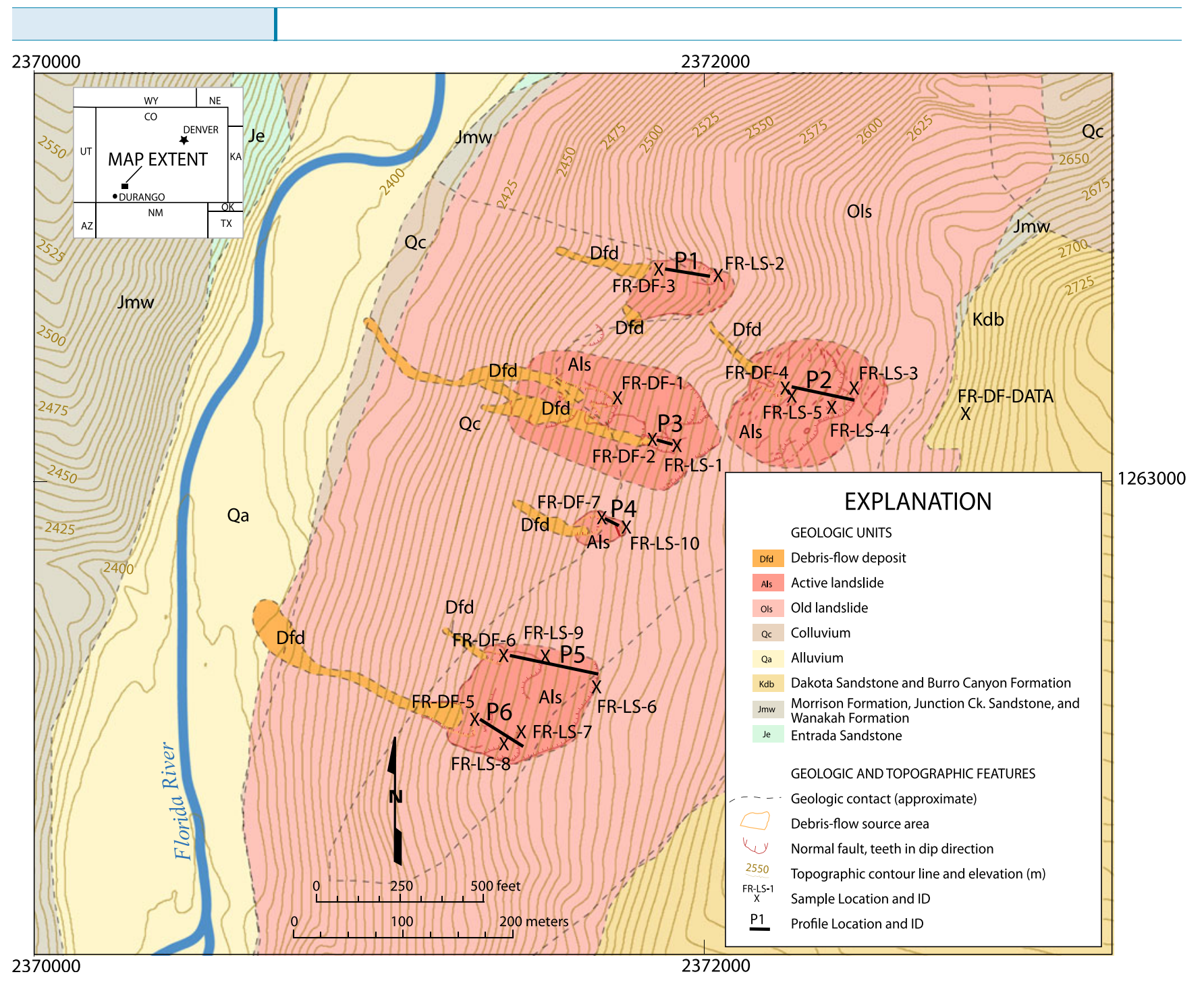

Fig. 2 Engineering geologic map, sample locations, and profile locations at the Florida River (FR) study site (Figure modified from Schulz et al. 2006)

age and consists of micaceous siltstone with thin to thick sandstone lenses and rhythmically interbedded, thin-graded, micaceous sandstone, and siltstone (Baldwin 1961).

The field area in the Portland Hills (FP, Fig. 1) consists of soils derived from Quaternary loess and the Miocene to Pliocene Troutdale Formation which mantles the Miocene Sentinel Bluffs unit of the Grande Ronde Basalt. The loess unit consists of quartzofeldspathic silt, and the Troutdale Formation is a conglomerate with minor interbeds of sandstone, siltstone, and claystone (Beeson et al. 1991). Soils from the Portland Hills field site are predominantly silts derived from loess deposits but may also contain well-rounded pebbles and cobbles from the Troutdale Formation and minor amounts of basalt.

The field area in Colorado (FR, Fig. 2) is primarily located within soils formed on the Dakota sandstone and Burro Canyon Formation as well as within less exposed sedimentary units of the Morrison Formation, Junction Creek Sandstone, Wanakah Formation, and Entrada Sandstone (Schulz et al. 2006). The Dakota Sandstone and Burro Canyon Formations are Cretaceous in age and consist of lightcolored sandstone and some conglomerate with minor amounts of fine-grained rocks and coal (Carroll et al. 1997).
Ninety-six landslide initiation sites were investigated. Eighty-eight of the landslides initiated within sandstonederived soils and 70 of these landslides occurred within the Tyee Formation, while 18 occurred within the Dakota Sandstone and Burro Canyon Formations. Five landslides occurred within the Portland loess/Troutdale Formation and three occurred within the Elkton Formation.

\section{Precipitation events}

The precipitation events that induced landslides in Oregon and Colorado were inherently different. Landslides were induced from heavy rainfall in Oregon and from rapid snowmelt in Colorado. However, soil-moisture conditions were already elevated in both geographic regions prior to the occurrence of landslides. It is important to note that debris flows mobilized within each study area indicating that these precipitation events were capable of initiating flows; yet, contemporaneous slides persisted as well.

Between February 1996 and January 1997, four intense rainfall events occurred in Western Oregon. Rainfall during these events exceeded the Oregon 24-h rainfall threshold for the initiation of fast-moving landslides established by Wiley (2000). The threshold 
Table 1 Initial vegetation conditions at each field area shown in Fig. 1 prior to landslide occurrence

\begin{tabular}{|c|c|c|c|c|c|c|}
\hline $\begin{array}{l}\text { Study } \\
\text { area }\end{array}$ & $\begin{array}{l}\text { Burned within } \\
3 \text { years of study }\end{array}$ & $\begin{array}{l}\text { Burned }>3 \text { years } \\
\text { of study }\end{array}$ & $\begin{array}{l}\text { Logged } \\
\text { after burn }\end{array}$ & $\begin{array}{l}\text { Logged before } \\
\text { burn }\end{array}$ & $\begin{array}{l}\text { Logged } \\
\text { only }\end{array}$ & $\begin{array}{l}\text { Neither logged } \\
\text { nor burned }\end{array}$ \\
\hline$B C$ & & X (1950s) & $x$ & & & \\
\hline CC & & & $x$ & & & \\
\hline $\mathrm{CHC}$ & & & & & $\begin{array}{l}\text { X? (trees cut in } 1992 \\
\text { air photos) }\end{array}$ & \\
\hline FP & & & & & & $X$ \\
\hline FR & $X(2002)$ & & & & & \\
\hline IV & X (July, 2003) & & X (Spring, 2004) & & & \\
\hline IVB & X (July, 2003) & & X (Spring, 2004) & & & \\
\hline MR & & & & & $X(2002)$ & \\
\hline $\mathrm{PH}$ & & & & & & $x$ \\
\hline SC & & & & $X(?)$ & & \\
\hline TM & & $x$ & $X$ (prior to 2001) & & & \\
\hline
\end{tabular}

BC Big Creek, CC Camp Creek, CHC Charlotte Creek, FP Forest Park, FR Florida River, IV Island View, IVB Island View B, MR Maupin Road, PH Powder House, SC Sulphur Creek, TM Tyee Mountain

is equal to 24 -h rainfall that exceeds $40 \%$ of mean December rainfall after antecedent rainfall of $203 \mathrm{~mm}$ (8.0 in.) has fallen during the months of October-November. Following these events, about 10,000 landslides occurred in Western Oregon (Hofmeister 2000) and resulted in disaster declarations by the Governor and responses by the Federal Emergency Management Agency. Maximum 24-h precipitation totals are shown in Table 2 for each of the four events. Rainfall-induced landslides occurred at the $\mathrm{CHC}$ and FP field site as a result of these storms.

Hundreds of landslides occurred in the Oregon Coast Range as a result of heavy rainfall during December 2005 and January 2006. Three large storms (Table 3) produced sufficient rainfall to exceed the Wiley (2000) threshold for initiating fast-moving landslides. The landslides investigated for this study that occurred as a result of these events included those at sites BC, CC, IV, IVB, MR, PH, SC, and TM (see Fig. 1 for locations).

The FR was active during the spring of 2005 (see Fig. 2 for location). This shallow landslide activity was triggered by elevated groundwater pressures by infiltration of rapid snowmelt into colluvium. Landslide activity during April 2005 was coincident with the highest precipitation amount on record up to that date

Table 2 Precipitation summary that resulted in landslides at the Charlotte Creek and Forest Park field areas (Fig. 1) in 1996-1997

\begin{tabular}{|lcl|}
\hline Date & $\begin{array}{c}\text { Maximum 24-h } \\
\text { precipitation }(\mathrm{mm})\end{array}$ & Gauge location \\
\hline 6-8 Feb 1996 & 179.1 & Portland, OR \\
\hline 18-19 Nov 1996 & 186.2 & Langlois, OR \\
\hline 8 Dec 1996 & 89.4 & Roseburg, OR \\
\hline 1 Jan 1997 & 72.6 & Ashland, OR \\
\hline
\end{tabular}

City locations are shown on Fig. 1 (Langlois is located $\sim 38$ miles SW of Coos Bay) during the 2004 water year (October 1, 2004-September 30, 2005) since 1941 (Schulz et al. 2006). Data from Schulz et al. (2006) indicate that shallow landslide activity was first observed in early April 2005 when snow depth had declined to $\sim 20 \%$ of the peak snow depth measured for the 2004 water year. The shallow landslides occurred within an old dormant landslide that was not investigated as part of this study.

\section{Methods and equipment}

Landslides were identified in each field area (Figs. 1, 2) but were only investigated if they appeared to be natural landslides (we excluded cut slopes and road-related landslides but included landslides in logged terrain). At each initiating landslide headscarp, numerous measurements were made to characterize the site. We mapped scarps using differential GPS (accuracy $\sim 30 \mathrm{~cm}$ RMS error) and measured multiple slope angles along the perimeter of the headscarp and slope-normal depth to the basal slip plane at approximately 2-m intervals along the axis of the landslide. We also collected undisturbed soil samples for density/ porosity measurements (typically 2-4 samples) and took a bulk sample which was split into two equal parts in the laboratory for grain-size analysis and index testing.

Undisturbed and bulk samples were collected from head scarps of each landslide at depths midway between the ground surface and the basal slip plane. Samples were collected near the end of the rainy season to minimize disturbance as soils were moist and readily sampled. Modified California sample tubes (6.2 $\mathrm{cm}$ diameter by $15.2 \mathrm{~cm}$ length) were driven into the soil using a fabricated driver that holds the tubes and allows for $10 \mathrm{~cm}$ of free space at the upper end of the sample to allow the tube to be overdriven into the ground. This method results in minimal disturbance of the soil during the sampling process. When it was not possible to push the tubes into the ground, the driver was lightly hammered using a plastic-coated, dead-blow hammer. Samples were recovered by digging the tube out of the ground 
Table 3 Precipitation summary for rain gauges shown on Fig. 1 that resulted in landslides in the Oregon Coast Range field areas during 2005-2006

\begin{tabular}{|c|c|c|c|c|}
\hline Date & Charlotte Ridge & Goodwin Peak & Clay Creek & Devils Graveyard \\
\hline \multicolumn{5}{|c|}{ Maximum $24 \mathrm{~h}$ precipitation ( $\mathrm{mm}$ of precipitation) } \\
\hline 30 Dec 2005 & 90.69 & 93.73 & 120.14 & 113.05 \\
\hline 10 Jan 2006 & 99.56 & 90.65 & 99.07 & 94.22 \\
\hline 17 Jan 2006 & 103.87 & 91.45 & 92.72 & 94.98 \\
\hline \multicolumn{5}{|c|}{ Antecedent Rainfall (mm of precipitation) } \\
\hline 0ct. 2005 & 96.77 & 245.87 & 113.03 & 122.17 \\
\hline Nov. 2005 & 225.81 & 348.74 & 297.43 & 291.34 \\
\hline Total & 322.58 & 594.61 & 410.46 & 413.51 \\
\hline
\end{tabular}

Antecedent rainfall exceeded $203 \mathrm{~mm}$ during October-November for each rain gauge. In addition, $40 \%$ of mean December rainfall, or average of $87 \mathrm{~mm}$ for stations located in Drain $(79 \mathrm{~mm})$ and Elkton $(95 \mathrm{~mm})$, OR was exceeded for each rain gauge (location shown on Fig. 1), a condition necessary to exceed the OR threshold for fast moving debris flows

and trimming the sample flush with the top and bottom of the tube. The tubes were capped and sealed with tape for transport. At times, rocks protruded beyond the ends of the tubes. These rocks were removed in the laboratory, and the volume removed $\left(V_{\mathrm{r}}\right)$ was measured by filling the void with a known volume of medium-grained Ottawa sand and subtracting the removed volume from the total tube volume $\left(V_{\mathrm{t}}\right)$. Soil samples were extruded in the laboratory, dried at $105^{\circ} \mathrm{C}$ for $24 \mathrm{~h}$, and the dry soil mass $\left(m_{\mathrm{d}}\right)$ recorded. The dry density $\left(\rho_{\mathrm{d}}\right)$ was then calculated as:

$\rho_{\mathrm{d}}=\frac{m_{\mathrm{d}}}{V_{\mathrm{t}}-V_{\mathrm{r}}}$

Grain-size distribution was measured using sieve and hydrometer methods as described in ASTM D-422 (ASTM 2002). Due to a large number of samples, the hydrometer method was run for $2 \mathrm{~h}$ to measure the total silt and clay fraction of sand-rich samples. However, the hydrometer method was run for a full $96 \mathrm{~h}$ for finegrained samples. Liquid limit (LL), plastic limit (PL), and plasticity index (PI) of the soils were measured using the procedure described in ASTM D-4318 (ASTM 2002).

At 30 of the landslide-initiation sites (Table 4), we measured the in situ saturated hydraulic conductivity, $k_{\text {sat }}(\mathrm{cm} / \mathrm{s})$, of the soil. Conductivity was measured above the headscarp in undisturbed material at depths approximately equal to those of the density samples, using an Ammozemeter (a constant-head, well permeameter manufactured by Ksat, Inc.) ${ }^{*}$. Measurements of volumetric water infiltrating the soil were continued until at least three consecutive, consistent measurements were made. At this time, it was assumed that a steady-state infiltration rate had been achieved, and the sample was field saturated. Measurements were typically continued for $1-2 \mathrm{~h}$. We calculated the field-saturated hydraulic conductivity using the singlehead analysis or "Glover" solution (Ammozegar 1989).

We classified each landslide in the field as a slide, flow, or partial flow. A slide was distinguished most commonly by the presence of intact blocks in the deposit, often capped with living pre-slide vegetation. Material deposited was usually just downslope from the initiation site, and grooves and striations along a basal slip surface were often present. Slides were also confirmed by a lack of flow features such as high mud marks on tree, levees, and lobate deposits from self-leveling of fluid-like material. An example of an open-slope slide is shown in Fig. 3.
Flows were characterized by evacuated source areas and coherent intact debris lobes. Channelized flows typically scoured the downslope channel to bedrock (Fig. 4), while open-slope flows typically deposited a thin veneer of material in the runout path (Fig. 3). Open-slope flows rarely transported material to the main channel. Partial flows contained a combination of features typical of both failure modes. It should be noted that for this study, all slides had visible deposits, while flows often merged with other flows and, therefore, did not always have a deposit that could be directly linked to the corresponding initiation site.

AMI was calculated for each initiating landslide by dividing the assumed gravimetric water content $\left(w_{\text {sat }}\right)$ at saturation by the LL of the corresponding soil (Ellen and Fleming 1987). Gravimetric water content at saturation was estimated as a percentage by

$w_{\text {sat }}=\frac{\rho_{\mathrm{w}}}{\rho_{\mathrm{d}}}-\frac{\rho_{\mathrm{w}}}{\rho_{\mathrm{p}}} \times 100$

where $\rho_{\mathrm{p}}$ is the particle density (assumed $2.65 \mathrm{~g} / \mathrm{cm}^{3}$ ), and $\rho_{\mathrm{w}}$ is particle density of water $\left(\sim 1 \mathrm{~g} / \mathrm{cm}^{3}\right)$. By assuming that an AMI $<1$ will result in a slide and an AMI $>1$ will result in a flow, we compared the failure mode predicted by the AMI values to the observed failure modes in the field.

We used a statistical hypothesis test ( $t$ test) to determine if a statistical difference existed between the means of the two populations being compared. This test was performed for normally distributed populations at the $95 \%$ confidence level. When the variances (tested using $F$ test) of the populations were equal ( $p$ value $>0.05$ ), we used a $t$ test that assumes equal variance; when variances were unequal ( $p$ value $\leq 0.05$ ), a $t$ test assuming unequal variance was applied. Probability values ( $p$ values) indicate the probability that the two sample population mean values being compared would be truly different from a single large population. For example, a $p$ value of 0.05 indicates that there is a $95 \%$ chance that the mean values of the two populations are different.

Linear discriminant analysis (LDA) is a statistical method used to define a linear combination of variables which separate two or more dependent variables. LDA was used to identify the principal variables that could be used individually or combined to classify a landslide initiation site as a slide or a flow. For each initiation site, the discriminate function score was computed by simple matrix multiplication. The two 


\section{Original Paper}

는

$\varkappa$
$\stackrel{\varkappa}{3}$
$y$

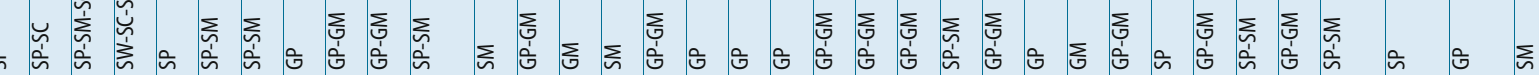

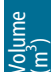

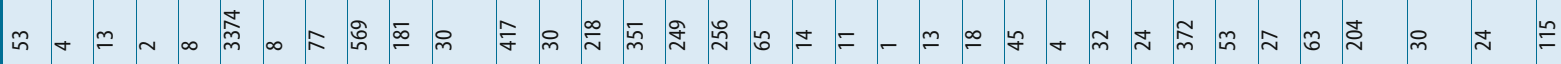

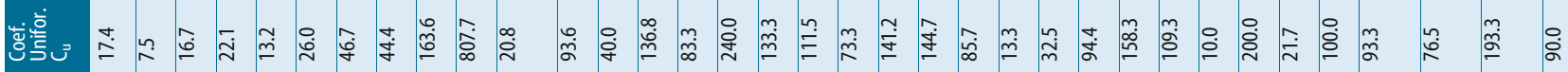

戓

중옹

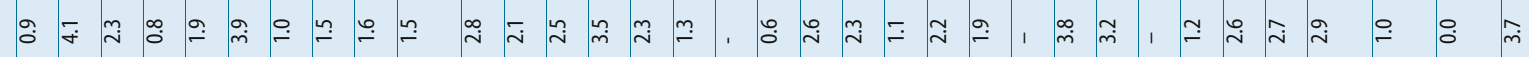

는용

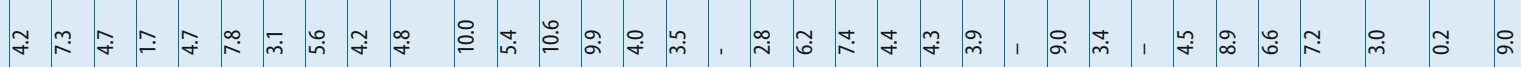

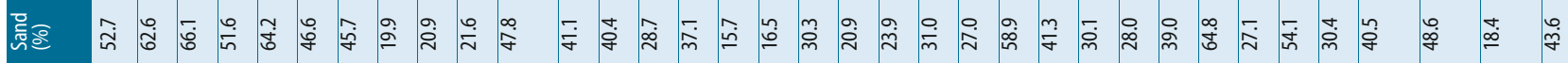

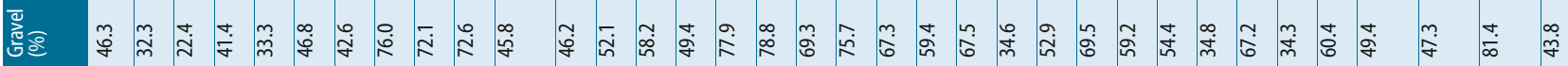

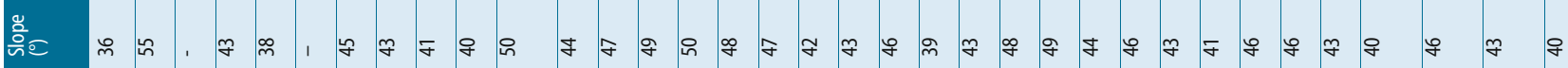

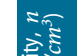

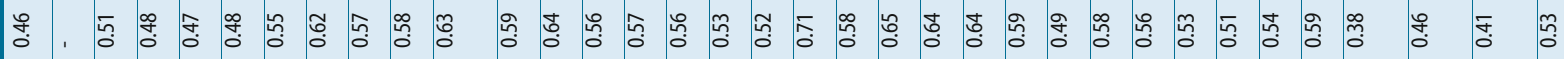

言

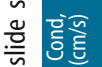

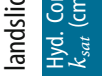

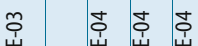

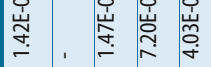

कृ

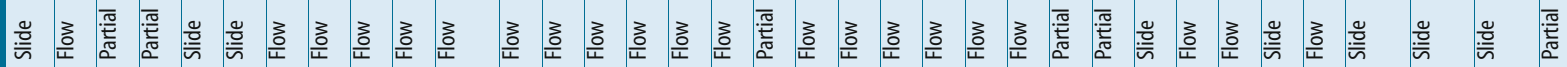
气.

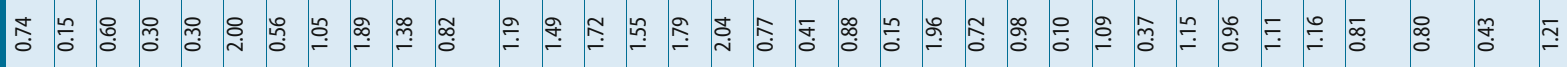

음

$\frac{\frac{2}{5}}{\frac{2}{\frac{D}{5}}}$

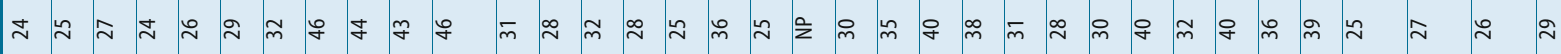

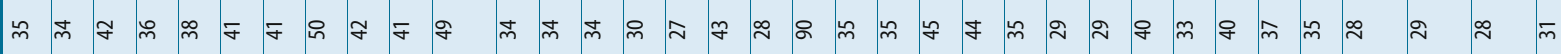

言

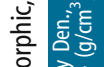

I., o 气̆

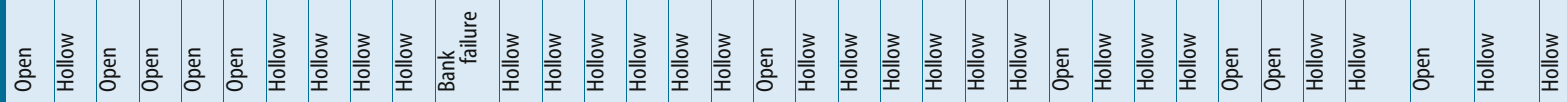

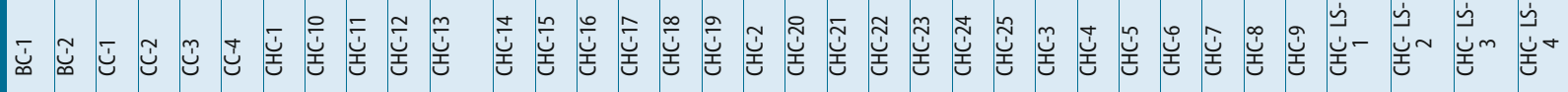




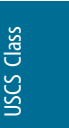

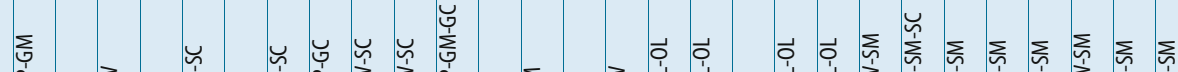

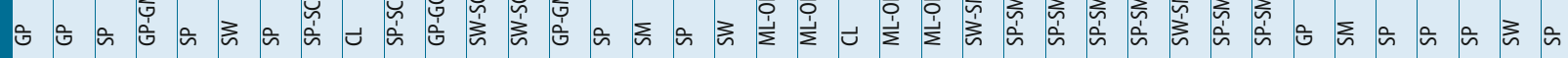

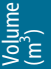
ป

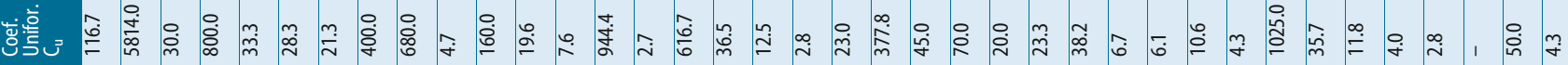

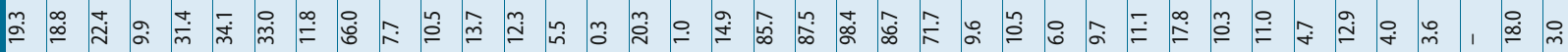

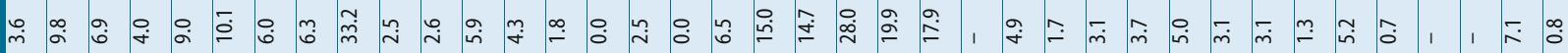

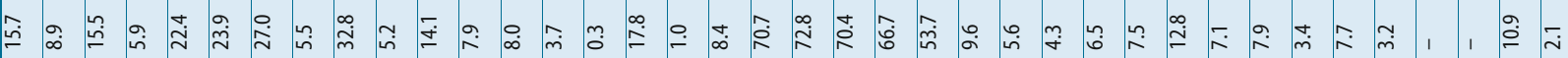

స̇

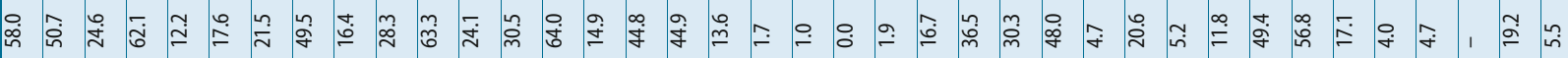

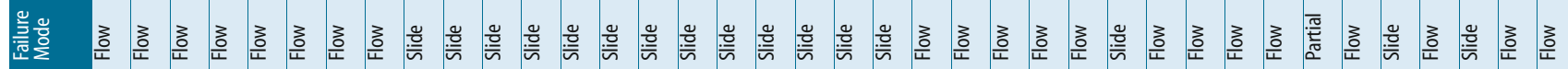

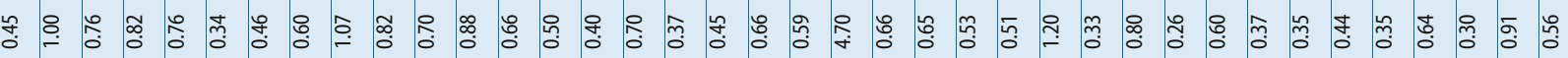

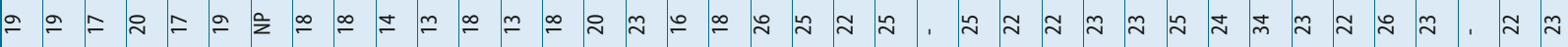




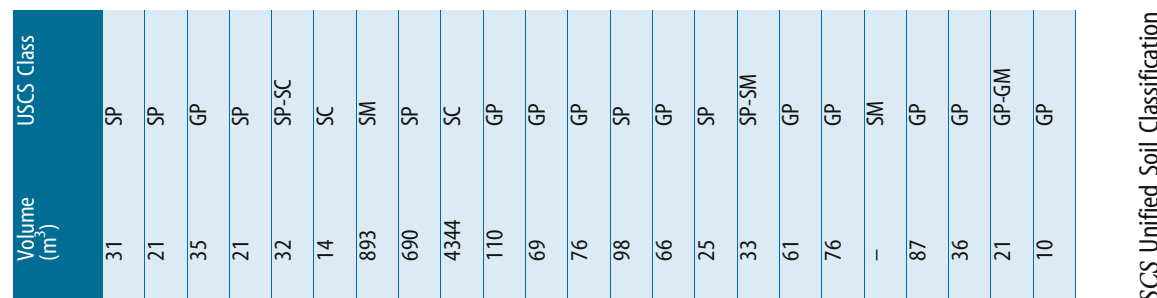

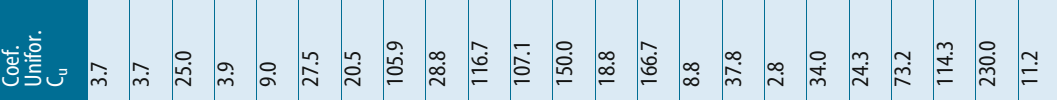

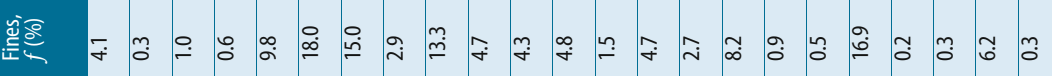

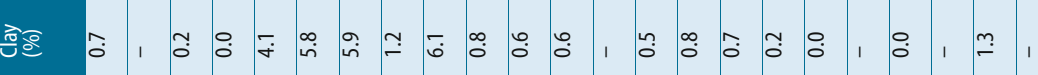

唁

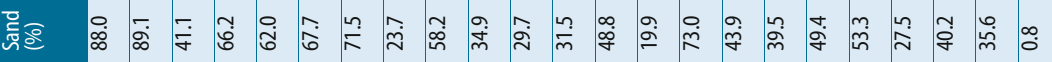

羟

হ

$\frac{2}{2}$

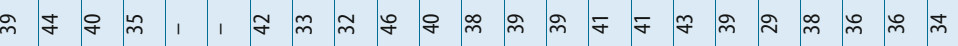

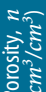

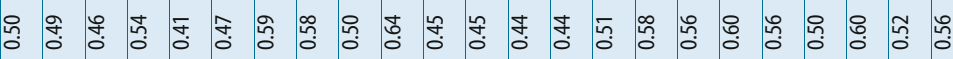

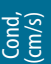

垔变

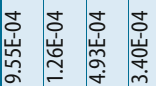

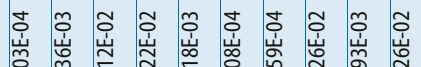

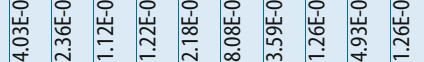

善器

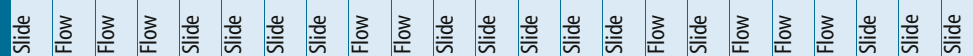

言要

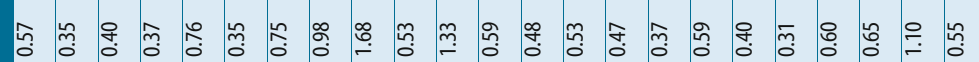

$\overrightarrow{2}$

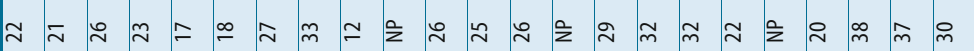

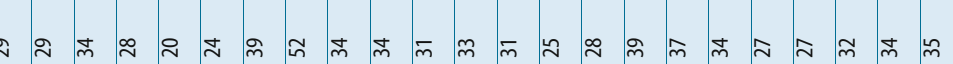

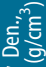

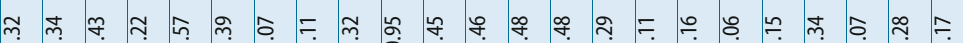

홀

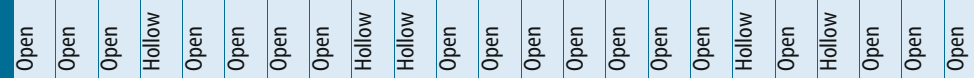

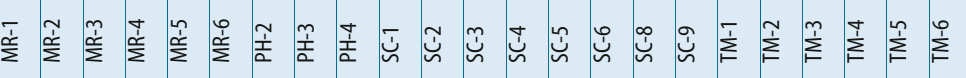




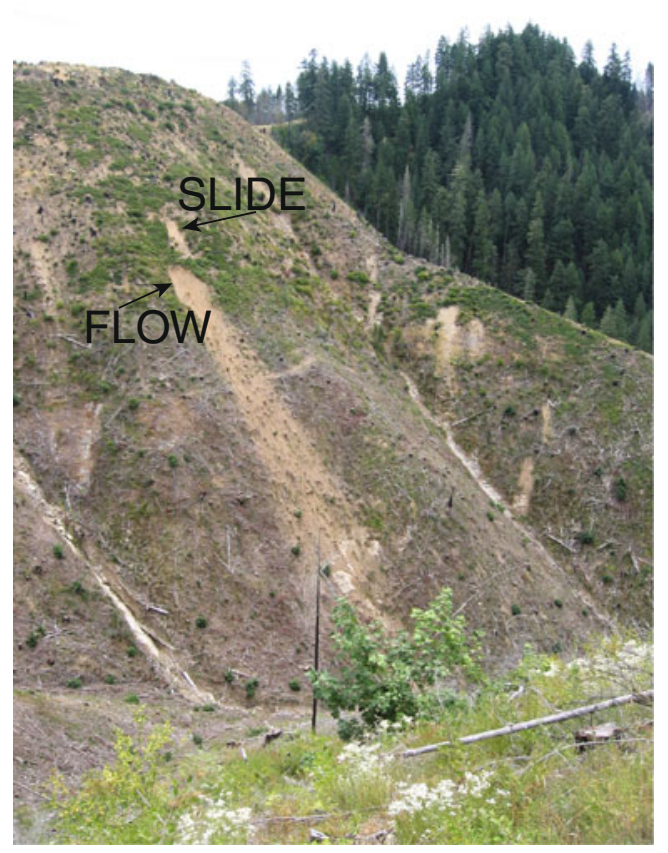

Fig. 3 Example of an open-slope slide (center of picture) that failed just above an open-slope flow in the IVB study site (see Fig. 1 for location)

scores were then compared, and the sample was assigned to the group (slide or flow) with the highest score. The variables tested using this method included: coefficient of curvature $\left(C_{\mathrm{c}}\right)$, coefficient of uniformity $\left(C_{\mathrm{u}}\right)$, various grain-size distribution parameters $\left(D_{10}, D_{30}, D_{50}, D_{60}\right.$, and gravel, sand, silt, clay, and fine-grained percentage $[f]), \rho_{\mathrm{d}}, k_{\text {sat }}$, slope $\left({ }^{\circ}\right)$, and Atterberg limits (LL, PL, PI). The variable, $C_{c}\left(C_{c}=\frac{D_{30}^{2}}{D_{10} D_{60}}\right)$, is a measure of the shape of the grain-size distribution curve and the variable, $C_{\mathrm{u}}\left(C_{u}=\frac{D_{60}}{D_{10}}\right)$, is an indicator of the range of particles for a given soil. The grain-size distribution parameter $(D)$ refers to the apparent grain-size diameter $(\mathrm{mm})$ and the subscripts

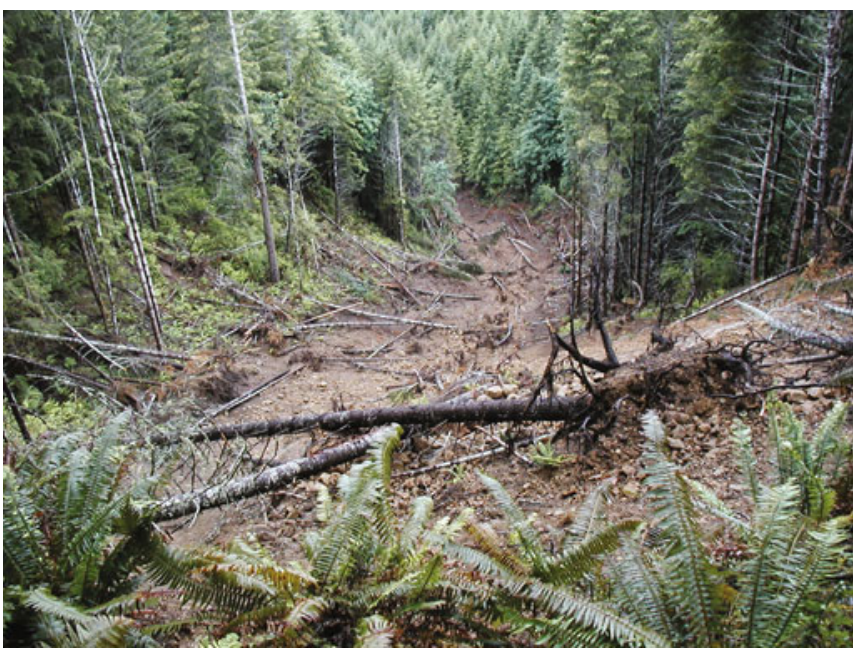

Fig. 4 Example of a channelized flow that initiated at the PH study site (see Fig. 1 for locations)
$(10,30,50,60)$ refer to the percent of the soil mass that is finer than that diameter. The variable $f$ consists of the percentage of the total dry soil mass passing the \#200 sieve (silt+clay).

The soil testing program was designed to test the hypothesis that material properties can be used to explain why some landslides mobilized into flows (flows) while others did not mobilize into flows (slides). The failure mode of landslides that initiate in hollows may be affected by hydrologic conditions and morphological influences such as angle of entry of failure to the channel, channel gradient, and volume of in-channel stored sediment. Landslides that initiate on open slopes are not affected by these factors. Therefore, to reduce potential geomorphic influences and to isolate the effects of material properties on landslide failure mode, we analyzed open-slope landslides (open-slope data set) separately from our analysis of the full dataset. Partial flows were not included in our analyses of the full data to further limit the analyses to material properties affecting only slide and flow landslide failure modes. We also test the applicability of AMI for predicting the failure mode.

\section{Results}

Table 2 provides a summary of field and laboratory results, Tables 5 and 6 contain the results of the predictive models that we tested, and Tables 7 and 8 contain a summary of the calculated statistics for the variables tested. The apparent influence of measured variables on landslide failure mode for the open-slope and full datasets follows.

\section{Slope}

When analyzing the full dataset, there is a statistically significant difference between the mean slopes of the two failure mode populations (Table 7). The mean slope is greater for flows than for slides suggesting that steeper slopes are more prone to flows. However, by limiting the data to the open-slope dataset, there is no statistical difference between the means of the two populations (Table 8).

\section{Volume}

The distribution of initial failure volumes (Volume, Table 2) is log-normal regardless of failure mode and the median volumes of slides and flows are equal (slide, $70 \mathrm{~m}^{3}$; flow $70 \mathrm{~m}^{3}$ ).

\section{Geomorphic setting}

Analysis of the full dataset (Table 2) shows that $87 \%$ of the slides and only $30 \%$ of the flows initiated on open slopes. If geomorphic setting was used as a predictor of failure mode, assuming all slides initiate on open slopes and all flows initiate in hollows, $77 \%$ of failure modes would be predicted correctly (Table 5).

\section{Approximate mobility index}

The AMI for each landslide in the full dataset is shown in Fig. 5. If $\mathrm{AMI}$ is used to predict failure mode by assuming that an $\mathrm{AMI}<1$ will result in a slide, whereas AMI $>1$ will result in a flow, $66 \%$ of failure modes would be predicted correctly (Table 5) and the mean AMI of the two failure mode populations are statistically different (Table 7). If we constrain the dataset to only landslides that initiate on open slopes, only $45 \%$ of failure modes would be predicted correctly using AMI (Table 6) and the mean AMI of the two failure mode populations are not statistically different (Table 8 ). 
Table 5 Model results using the full dataset to predict landslide failure mode using (a) threshold dry density, (b) AMI, and (c) geomorphic setting

\section{a}

\begin{tabular}{|c|c|c|}
\hline \multicolumn{3}{|c|}{ Threshold Density: 79.3\% Correct (69 of 87) } \\
\hline Predicted & Flow & Slide \\
Observed & & \\
\hline Flow (n=50) & 41 & 9 \\
& $(82 \%)$ & $(18 \%)$ \\
\hline Slide(n=37) & 9 & 28 \\
& $(24 \%)$ & $(76 \%)$ \\
\hline
\end{tabular}

b

\begin{tabular}{|c|c|c|}
\hline \multicolumn{2}{|c|}{ AMI: 65.5\% Correct (57 of 87) } \\
\hline Predicted & Flow & Slide \\
\hline Observed & & \\
\hline Flow (n=50) & 44 & 6 \\
& $(88 \%)$ & $(12 \%)$ \\
\hline Slide(n=37) & 24 & 13 \\
& $(65 \%)$ & $(35 \%)$ \\
\hline
\end{tabular}

c

Geomorphic Setting: $77.3 \%$ Correct (68 of 88 )

\begin{tabular}{|c|c|c|}
\hline Predicted & Flow & Slide \\
\hline Flow $(\mathbf{n}=\mathbf{5 0})$ & 35 & 15 \\
& $(70 \%)$ & $(30 \%)$ \\
\hline Slide $(\mathbf{n}=\mathbf{3 8})$ & 5 & 33 \\
& $(13 \%)$ & $(87 \%)$ \\
\hline
\end{tabular}

Values in blue indicate the number of sites for which the predicted behavior matched the observed behavior. Values in red indicate the number of sites where predicted and observed behavior did not match

Dry density, fine-grained content, and saturated hydraulic conductivity

Among the individual variables analyzed using LDA, a combination of $\rho_{\mathrm{d}}, k_{\text {sat }}$, and $f$ showed the highest success rate for predicting failure mode $(89 \%$ using full dataset; $86 \%$ using open-slope dataset). However, the inclusion of the variable, $k_{\mathrm{sat}}$, in this method reduced the sample population (flows: $n=27$ (full dataset), $n=22$ (open-slope dataset)). The linear discriminate functions for the two dependent variables (slide and flow) using the full dataset are as follows:

slide $=642.37 k_{\text {sat }}+81.89 \rho_{\mathrm{d}}+.13 f-56.57$

flow $=337.06 k_{\text {sat }}+72.45 \rho_{\mathrm{d}}+.35 f-44.81$

Scores are calculated using both Eqs. 3 and 4, and the predicted failure mode corresponds to the highest score. For the full dataset, LDA analysis of the individual variables $\left(\rho_{\mathrm{d}}, k_{\mathrm{sat}}\right.$, and f) resulted in correct prediction of the failure mode for $71 \%, 67 \%$,
Table 6 Model results using the open-slope dataset to predict landslide failure mode using (a) threshold dry density and (b) AMI

\begin{tabular}{|c|c|c|}
\hline \multicolumn{2}{|c|}{ Threshold Density: $76.6 \%$ Correct (36 of 47) } \\
\hline Predicted & Flow & Slide \\
Observed & & \\
\hline Flow (n=15) & 12 & 3 \\
$(80 \%)$ & $(20 \%)$ \\
\hline Slide (n=32) & 8 & 24 \\
& $(25 \%)$ & $(75 \%)$ \\
\hline
\end{tabular}

$\mathbf{a}$

\begin{tabular}{|c|c|c|}
\hline \multicolumn{3}{|c|}{ AMI: 44.7\% Correct (21 of 47) } \\
\hline Predicted & Flow & Slide \\
\hline Observed & & \\
\hline Flow (n=15) & $\begin{array}{c}12 \\
(80 \%)\end{array}$ & $\begin{array}{c}3 \\
(20 \%)\end{array}$ \\
\hline Slide (n=32) & 23 & 9 \\
& $(72 \%)$ & $28 \%)$ \\
\hline
\end{tabular}

b

Values in blue indicate the number of sites for which the predicted behavior matched the observed behavior. Values in red indicate the number of sites where predicted and observed behavior did not match

and $55 \%$ of the initiation sites, respectively, using the full dataset. For the open-slope dataset, $65 \%, 64 \%$, and $36 \%$ of failure modes were correctly predicted for the $\rho_{\mathrm{d}}, k_{\text {sat }}$, and $f$ variables, respectively.

Tables 7 and 8 summarize the statistical results ( $F$ test, $t$ test) for the individual variables tested. Although a statistically significant difference in the means of the two failure mode populations exists for the individual variables, $\rho_{\mathrm{d}}$ and $k_{\mathrm{sat}}$, when using the entire dataset (Table 7), there is no statistical difference in the two population means for either variable when using the open-slope dataset.

The distribution of landslide failure mode with respect to $f$ and $\rho_{\mathrm{d}}$ is shown in Fig. 6 (full dataset) and in Fig. 7 (open-slope data set). Figure 6 includes previously published data from large-scale flume experiments (Logan and Iverson 2007; Iverson et al. 2000) and from California field sites (Gabet and Mudd 2006), which are referred to as "Flume" and "G\&M," respectively. These two additional datasets were included because the authors investigated the influence of

Table 7 Statistical summary of $p$ values for $F$ and $t$ tests $(\alpha=0.05)$ for individual variables using the full dataset

\begin{tabular}{|llll|} 
Variable & Population size & $F(p$ value $)$ & $T$ ( $p$ value $)$ \\
\hline$\rho_{\text {dev }}$ & 87 & 0.13 & $2.13 \mathrm{E}-07^{\mathrm{a}}$ \\
\hline$\rho_{\mathrm{d}}$ & 88 & 0.19 & $8.65 \mathrm{E}-06^{\mathrm{a}}$ \\
\hline AMI & 87 & 0.21 & $9.02 \mathrm{E}-04^{\mathrm{a}}$ \\
\hline Slope & 84 & 0.42 & $3.08 \mathrm{E}-03^{\mathrm{a}}$ \\
\hline$k_{\text {sat }}$ & 27 & $0.02^{\mathrm{a}}$ & $0.04^{\mathrm{a}}$ \\
\hline$f$ & 88 & $9.3 \mathrm{E}-04^{\mathrm{a}}$ & 0.64 \\
\hline
\end{tabular}

${ }^{a}$ Statistically significant figures 
Table 8 Statistical summary of $p$ values for $F$ and $t$ tests $(\alpha=0.05)$ for individual variables using the open-slope dataset

\begin{tabular}{llll} 
Variable & Population size & $F(p$ value $)$ & $T(p$ value $)$ \\
\hline$\rho_{\text {dev }}$ & 47 & 0.32 & $3.75 \mathrm{E}-03^{\mathrm{a}}$ \\
\hline$\rho_{\mathrm{d}}$ & 48 & 0.06 & 0.09 \\
\hline Slope & 43 & 0.22 & 0.09 \\
\hline$k_{\text {sat }}$ & 22 & 0.10 & 0.10 \\
\hline AMl & 47 & 0.35 & 0.17 \\
\hline$f$ & 47 & $9.5 \mathrm{E}-06^{\mathrm{a}}$ & 0.75
\end{tabular}

${ }^{\text {a }}$ Statistically significant figures

material properties on landslide failure mode in a fashion similar to this study.

It is apparent in Figs. 6 and 7 that a threshold curve divides the two failure modes, with flows plotting above the threshold curve and slides plotting below the curve. The best-fit curve that divides failure modes and equalizes the number of Type I (predicted slide, observed flow) and Type II errors (predicted flow, observed slide) (Table 5) is the threshold density $\left(\rho_{\mathrm{td}}\right)$ :

$\rho_{\mathrm{td}}=8.48 \times 10^{-6} f^{3}-1.33 \times 10^{-3} f^{2}+5.27 \times 10^{-2} f+1.04$

where $f$ is the fine-grained fraction of the soil.

In order to analyze the statistical significance of $\rho_{\mathrm{td}}$ as a predictor variable for failure mode, we normalized the density measurements with respect to $\rho_{\mathrm{td}}$ as follows:

$\rho_{\mathrm{dev}}=\rho_{\mathrm{td}}-\rho_{\mathrm{d}}$

where $\left(\rho_{\mathrm{dev}}\right)$ is the deviation of the sample density $\left(\rho_{\mathrm{d}}\right)$ with respect to $\rho_{\mathrm{td}}$. Positive values for $\rho_{\mathrm{dev}}$ indicate that $\rho_{\mathrm{d}}<\rho_{\mathrm{td}}$ (susceptible to flowing) and negative values indicate that $\rho_{\mathrm{d}}>\rho_{\mathrm{td}}$ (susceptible to sliding). $F$ and $t$ tests indicate that for the variable $\rho_{\text {dew }}$ a statistically significant difference in the means of the two failure mode populations exists for both the full dataset and the open-slope dataset (Tables 7 and 8 ). Deviation density positively identifies $79 \%$ of failure

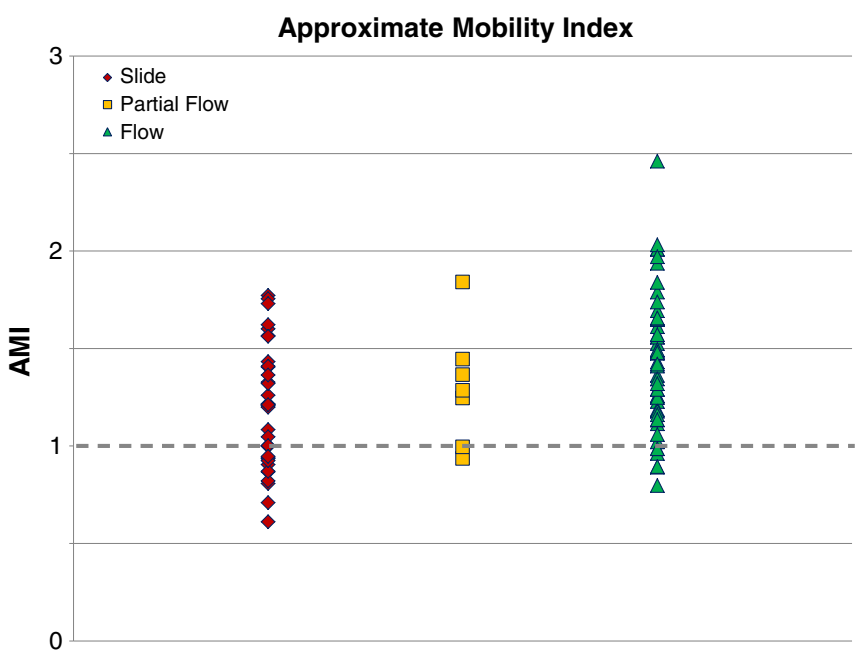

Fig. $5 \mathrm{AMI}$ according to landslide failure mode

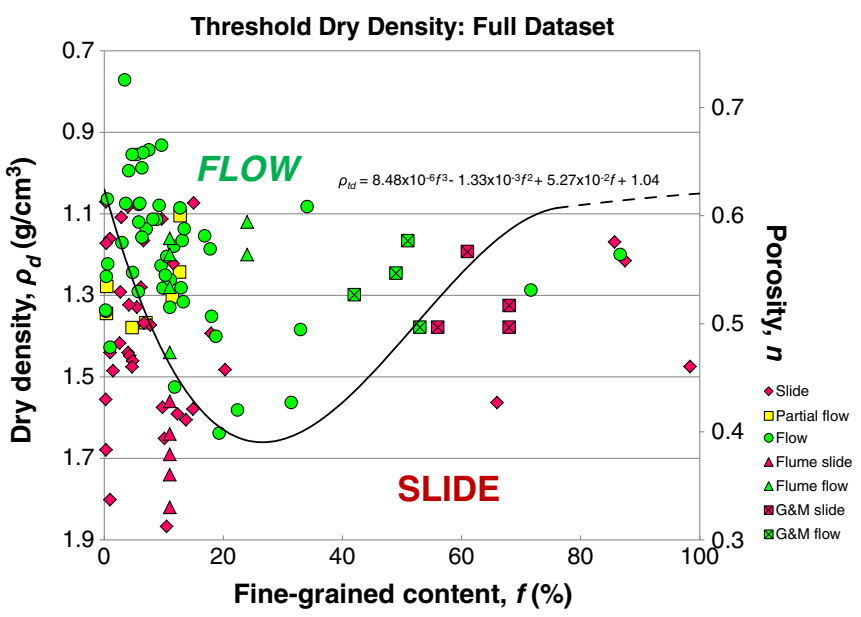

Fig. 6 Dry density threshold boundary $\left(\rho_{\text {td }}\right)$ defined by Eq. 5 showing the division between slides and flows using the full dataset (Table 2) where $f$ is the silt and clay fraction of the soil. Green symbols are flows, yellow symbols are partial flows, and red symbols are slides. "Flume" data from Logan and Iverson 2007; Iverson et al. 2000; "G\&M" data from Gabet and Mudd 2006

modes using the full dataset and $77 \%$ using the open-slope dataset.

The distribution of soil density at the FR study area (Fig. 2) can provide some insight into the origins of soils looser than the criticalstate value. Figure 2 shows that the debris-flow initiation sites are located within active slide deposits and in most cases are located at slide toes. Density profiles (expressed as $\rho_{\mathrm{dev}}$ ) extending from debrisflow headscarps up to the headscarps of their containing slides (along profile lines P1-P6 in Fig. 2) are shown in Fig. 8. Five of the six profiles show that $\rho_{\mathrm{dev}}$ is positive, or looser than $\rho_{\mathrm{td}}$, for debris-flow source areas. Generally, $\rho_{\mathrm{dev}}$ is negative, or denser than $\rho_{\mathrm{td}}$, above the debrisflow headscarp and throughout the corresponding up-hill slide deposit.

Discussion

Geomorphic setting is a good indicator of landslide failure mode suggesting that slides typically occur on open slopes and flows

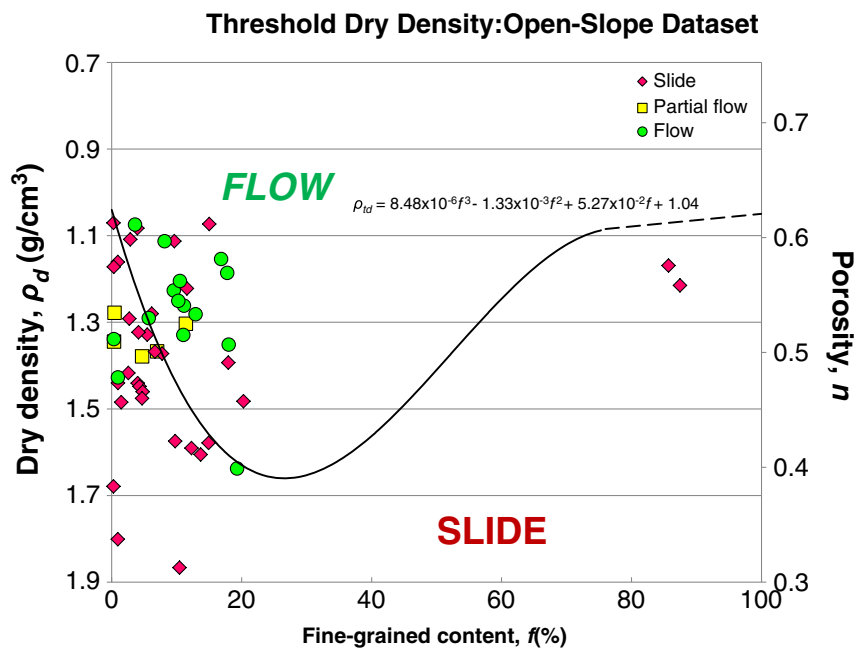

Fig. 7 Dry density threshold boundary $\left(\rho_{\mathrm{td}}\right)$ defined by Eq. 5 showing the division between slides and flows using the open-slope dataset (Table 2). Green symbols are flows, yellow symbols are partial flows, and red symbols are slides 
Original Paper

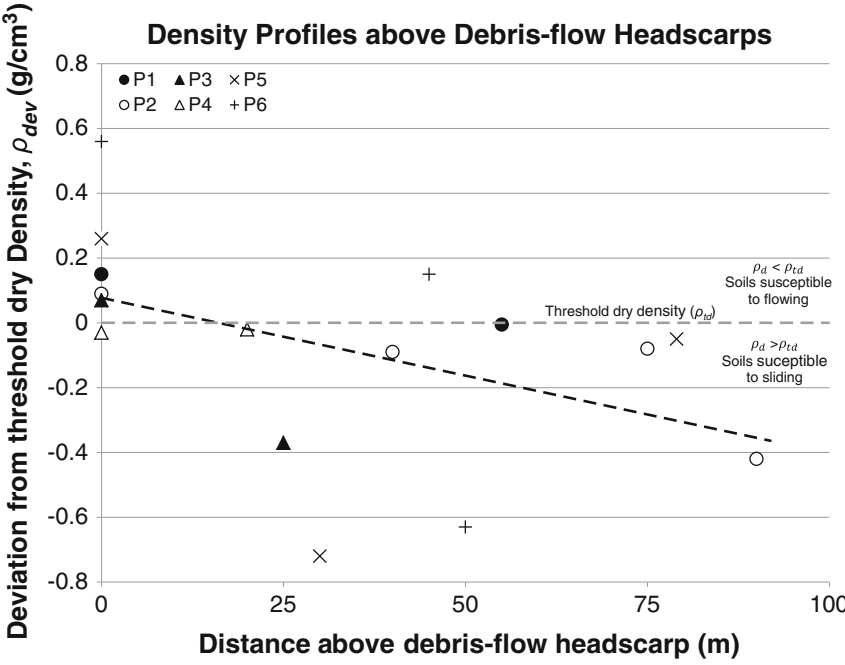

Fig. 8 Density profiles for Florida River sample locations along profile lines (P1-P6) shown in Fig. 2. The trend line corresponds to all data on the plot. The threshold density $\left(\rho_{\mathrm{td}}\right)$ corresponds to $\rho_{\mathrm{dev}}=0$; positive values for $\rho_{\mathrm{dev}}$ indicate soils susceptible to flowing; negative values for $\rho_{\mathrm{dev}}$ indicate soils susceptible to sliding

typically occur in hollows. Likely explanations for this spatial occurrence are that flows may initiate from dilated slide debris in locations where water is abundant. Hollows are indicated by topographic concavities marking the beginning of the stream channel, and open slopes are generally indicated by parallel topographic contours that form the hillslopes above hollows (Hack and Goodlet 1960). Sources of dilated material are likely upslope from hollows on open slopes where slides are common. The dilated slide deposits may accumulate in the hollow where topographic concavities provide an avenue for groundwater to converge and saturate the soil. Subsequent failure in the saturated soil would be contractive. When contraction rates exceed diffusive pore-pressure rates, pore pressures can increase beyond hydrostatic pressures which can transform some landslides into rapidly moving liquefied flows (Rudiniki 1984; Iverson and LaHusen 1989).

Landslide failure mode is predicted with the highest success rate for both the open-slope and full datasets using the initial dry density $\left(\rho_{\mathrm{d}}\right)$ and fine-grained fraction $(f)$ of the soil. The same threshold curve (Eq. 3) divides slide and flow failure modes when using $\rho_{\mathrm{d}}$ and $f$ as predictor variables for the full dataset (Fig. 6), as well as for the open-slope dataset (Fig. 7). A previously published critical-state density value $\left(\rho_{\mathrm{d}}=1.51 \mathrm{~g} / \mathrm{cm}^{3}, f=11 \%\right)$ for well-graded material tested at low normal stress at the USGS large-scale flume (Reid et al. 2008) falls on the threshold curve, and the threshold curve is consistent with published field data from California (Gabet and Mudd 2006). Among all the variables tested, $\rho_{\mathrm{dev}}$ (which is a function of $\rho_{\mathrm{d}}$ and $f$ and is shown in Eq. 6) is the only variable that shows a statistically significant difference in the means of the two failure mode populations for both the full and open-slope datasets.

The results of the LDA analysis suggest that the principal components for discerning failure modes are $\rho_{\mathrm{d}}, f$, and $k_{\text {sat }}$. The inclusion of $\rho_{\mathrm{d}}$ and $f$ in Eqs. 3 and 4 reinforces the conclusion that these variables can be used to estimate $\rho_{\text {td }}$ shown in Figs. 6 and 7 and defined by Eq. 5. The inclusion of $k_{\text {sat }}$ in Eqs. 3 and 4 supports the physical-based theory that contractive soils will cause increased pore pressures only when the contraction rate exceeds the pore-pressure diffusion rate of the soil (Rudnicki 1984; Iverson and LaHusen 1989). When pore pressures increase beyond hydrostatic pressures, complete liquefaction leading to flow behavior rather than slide behavior is very likely. Therefore, contraction and pore-pressure diffusion rates are of paramount importance in the liquefaction process.

More than $85 \%$ of the samples shown in Table 2 have $L L<40$ (low to moderate plasticity), $C_{\mathrm{u}}>8$ (well-graded), and $f<18 \%$ (few to moderate fines); therefore, Eqs. 3-6 are most applicable to soils meeting these criteria. When these criteria are met, Eq. 5 predicted $81 \%$ of failure modes correctly for the full dataset and $82 \%$ for the open-slope dataset. In fact, the only slide (IVB-1) not predicted correctly by applying Eqs. 3 and 4 has material properties that do not meet these criteria. Furthermore, four of the nine slides (F-LS-8, IV-2, IVB-1, and PH-3; Table 2) predicted incorrectly by Eq. 5 have material properties that do not meet these criteria, and three are borderline cases (CHC-5, MR-6, and PH-2; Table 2).

Equations 3-6 seem to perform poorly at very low fine-grained contents, especially $f<1 \%$. All of the flows (MR-2 and MR-3; Table 2) predicted incorrectly using Eqs. 3 and 4 have $f<1$, and five of the nine flows predicted incorrectly by applying Eq. 5 have $f<1$. Equation 5 tends to under predict threshold density for $f<1$. For example, an open-slope debris flow initiated at MR-3 with $\rho_{\mathrm{d}}=1.43 \mathrm{~g} / \mathrm{cm}^{3}$ (Table 2) and Eq. 5 incorrectly predicts $\rho_{\text {td }}$ to be $1.08 \mathrm{~g} / \mathrm{cm}^{3}$. At these low finegrained contents $(f<1)$, cohesion is very low (virtually absent) and $k_{\text {sat }}$ is high, which would promote rapid failure velocity (Gabet and Mudd 2006). Rapid shearing rates and momentum of the failing mass might be sufficient to promote mobilization. For $f<1 \%$, we suspect that $\rho_{\text {td }}$ could be as high as $1.47 \mathrm{~g} / \mathrm{cm}^{3}$ which is consistent with published critical-state densities from triaxial laboratory tests for clean sands under a similar normal stress of $10 \mathrm{kPa}$ (Poulos et al. 1985).

Well-graded materials are common in debris-flow deposits (Troxell and Peterson 1937; Krumbein 1940, 1942; Sharp and Nobles 1953; Bull 1964; Rodine and Johnson 1976) and are one of several factors that allow flows to travel down relatively gentle slopes (Rodine and Johnson 1976). Poorly graded soils will have a lower critical-state density than well-graded soils (Poulos et al. 1985). For example, poorly graded soils that contain predominantly gravel-sized particles will have characteristic critical-state densities governed by the collision and rearrangement of the particles during shear. The addition of a small amount of finer-grained particles may fill a portion of the voids between the gravel-sized particles and increase the density of the soil, but the critical-state density will still be dictated by the colliding and sliding of the larger particles after failure. This relation is supported by the downward-trending slope shown in Figs. 6 and 7 for $f<28 \%$. As $f$ increases beyond $28 \%$, the curve takes on an upward-trending slope. At this point, the critical-state density begins to be dictated more by the collision of the matrix particles as soils begin to trend back toward a more uniform distribution and the critical-state density begins to decrease. Soils with high organic matter or soils with low particle densities will exhibit lower critical-state densities than suggested by Eq. 5. Critical-state density will also increase with increasing normal stress. Therefore, our threshold curve should be considered as a maximum density curve above which shallow flows are unlikely.

The density profiles from the Florida River field area (see Fig. 2 for profile locations $\mathrm{P}_{1-\mathrm{P} 6)}$ are shown in Fig. 8. These data suggest that soils initially denser than $\rho_{\mathrm{td}}$ are found above debris flow headscarps in slides that dilate upon shearing and are capable of dilating to a looser state than the threshold density. At debris-flow 
headscarps, $\rho_{\mathrm{dev}}$ is positive and the soil is prone to flowing in subsequent slope failures. This demonstrates that dense soils can evolve over time from dilative soils that are subject to sliding or creeping to loose soils that are prone to flowing. Bioturbation can further decrease density as organisms tend to burrow in loose soils that are easy to penetrate and redistribute.

\section{Conclusions}

Our analyses of the full dataset indicate that landslide failure mode is primarily influenced by both the geomorphic setting and the material properties found at initiation sites. Analyses of the open-slope dataset indicate that failure mode is primarily influenced by the soil's material properties alone. Our conclusions are as follows:

1. Slope does not influence the failure mode (sliding or flowing) for landslides that initiate on open slopes, but it may influence the failure mode in hollows (Tables 7-8).

2. Failure volume does not influence failure mode in our study area.

3. Although the simplified geomorphic setting (open-slope and hollow) seems to be a good predictor for sliding or flowing (77\% correctly predicted, Table 5), other inherent morphological factors could contribute to the mobilization process such as angle of entry of failure to the channel, channel gradient, volume of in-channel stored sediments, and hydrologic effects. To isolate the influence of material properties on failure mode, we analyzed open-slope failure separately from our full dataset.

4. AMI is an inconsistent predictor of failure mode. Although it performs moderately well using the full dataset (66\% correctly predicted, Table 5), it performs poorly when tested using the open-slope dataset ( $45 \%$ correctly predicted, Table 6 ).

5. The variables $\rho_{\mathrm{d}}, f$, and $k_{\text {sat }}$ can be combined using the linear discriminate functions in Eqs. 2 and 3 and are good predictor variables for failure mode $(89 \%$ correctly predicted for the full dataset and $86 \%$ correctly predicted for the open-slope dataset). However, these individual variables are poor predictors of failure mode.

6. The variable $\rho_{\mathrm{td}}$ (defined by Eq. 5 and shown in Figs. 6 and 7 ) closely approximates the critical-state density, and Eq. 5 is most suitable for shallow (depth $<5 \mathrm{~m})$, well-graded soils $\left(C_{\mathrm{u}}>8\right)$, with few to moderate fines $(f<18 \%)$, and with low liquid limits $(\mathrm{LL}<$ 40).

7. The variable $\rho_{\mathrm{dev}}$ (calculated as the difference between the in-situ density and the critical density, which is a function of $\rho_{d}$, and $f$ ) is a good predictor variable for failure mode and performs well using both the full (79\% correctly predicted, Table 5) and openslope datasets $(77 \%$ correctly predicted, Table 6$)$. This variable $\left(\rho_{\text {dev }}\right)$ is the only tested variable that shows a statistically significant difference in the means of the two failure mode populations for both the full and open-slope datasets.

\section{Acknowledgements}

Jason Hinkle assisted in obtaining access to the Oregon Coast Range field sites and helped formulate the primary objectives for this research. Jeffrey Coe, William Schulz, and Rex Baum provided comments that greatly improved the quality and clarity of this paper. Any use of trade, product, or firm names in this website or publication is for descriptive purposes only and does not imply endorsement by the US Government.

\section{References}

American Society for Testing and Materials (2002) Annual book of ASTM Standards, vol 4.08. American Society for Testing and Materials, Philadelphia, $\mathrm{p} 1672$

Amoozegar A (1989) Comparison of the Glover solution with the simultaneousequations approach for measuring hydraulic conductivity. Soil Sci Society Am J 53:1362-1367

Anderson SA, Reimer MF (1995) Collapse of saturated soil due to reduction in confinement. J Geotech Engineering 121:216-220

Atkinson J (1993) An Introduction to the Mechanics of Soils and Foundations through Critical-State Soil Mechanics. McGraw-Hill, London, p 337

Baldwin EM (1961) Geologic map of the lower Umpqua River area, Oregon. US Geological Survey Oil and Gas Investigation Map: OM 204

Beeson MH, Tolan TL, Madin IP (1991) Geologic map of the Portland quadrangle, Multnomah and Washington Counties, Oregon, and Clark County, Washington: State of Oregon Geological Map Series GMS-75, 1 sheet, scale 1:24,000

Benda L, Cundy TW (1990) Predicting deposition of debris flows in mountain channels. Can Geotech J 27:409-417

Benda L, Dunne T (1987) Sediment routing by debris flow. In: Beschta RL, Blinn T, Grant GE, Ice GG, Swanson FJ (eds) Erosion and Sedimentation in the Pacific Rim. IAHS, Wallingford, pp 213-223, Publication 165

Bovis MJ, Dagg BR (1992) Debris flow triggering by impulsive loading: mechanical modeling and case studies. Can Geotech J 29:345-352

Brayshaw D, Hassan MA (2009) Debris flow initiation and sediment recharge in gullies. Geomorphology 109:122-131

Bull WB (1964) Alluvial fans and near-surface subsidence in Western Fresno County, California. Q J Eng Geol 7:339-349

Cannon SH, Gartner JE, Parrett C, Parise M (2003) Wildfire-related debris flow generation through episodic progressive sediment bulking processes, western U.S.A. In: Rickenmann D, Chen CL (eds) Debris-Flow Hazards Mitigation: Mechanics, Prediction, and Assessment. Mill, Rotterdam, pp 71-82

Carroll CJ, Kirkham RM, Wracher A (1997) Geologic map of the Rules Hill quadrangle, La Plata County, Colorado: Colorado Geological Survey, scale 1:24,000

Casagrande A (1976) Liquefaction and cyclic deformation of sands, a critical review. Harvard Univ Soil Mech Ser 88:27

Coe JA, Reid ME, Brien DL, Michael JA (2011) Assessment of topographic and drainage network controls on debis-flow travel distance along the west coast of the United States. In: The 5th International Conference on Debris-Flow Hazards Mitigation: Mechanics, Prediction and Assesment, June 14-17, 2011. University of Padua, Italy

Day RW (1994) Case study of debris flow. J Performance Constructed Facilities, ASCE 8 (3):192-200

Eckersley JD (1990) Instrumented laboratory flowslides. Geotechnique 40(3):489-502 Ellen SD, Fleming RW (1987) Mobilization of debris flows from soil slips, San Francisco Bay region, California. In: Costa JE, Wieczorek GF (eds), Debris flows/avalanches: Process, recognition and mitigation, Geological Society of America, Reviews in Engineering Geology, 7:31-40

Fuchu D, Lee CF, Sijing W, Feng Y (1999) Stress-strain behaviour of a loosely compacted volcanic derived soil and its significance to rainfall-induced fill slope failures. Eng Geol 53:359-370

Gabet E, Mudd SM (2006) The mobilization of debris flows from shallow landslides. Geomorphology 74:207-218

Hack JT, Goodlet JC (1960) Geomorphology and forest ecology of a mountain region in the Central Appalachians. US Geol Surv Professional Paper 347:67

Hofmeister RJ (2000) Slope failures in Oregon, GIS inventory for three 1996/97 storm events. Oregon Dept Geol Miner Industries Special Paper 34:20, 1 compact disc

Iverson RM (1997) The physics of debris flows. Rev Geophys 35:245-296

Iverson RM (2005) Regulation of landslide motion by dilatancy and pore pressure feedback. J Geophys Res 110:F02015. doi:10.1029/2004JF000268

Iverson RM, LaHusen RG (1989) Dynamic pore-pressure fluctuations in rapidly shearing granular materials. Science 246:796-799

Iverson RM, Reid ME, LaHusen RG (1997) Debris-flow mobilization from landslides. Ann Rev Earth Planetetary Sci 25:85-138

Iverson NR, Hooyer TS, Baker RW (1998) Ring-shear studies of till deformation: Coulomb-plastic behavior and distributed strain in glacier beds. J Glaciol 44:634-642 
Iverson RM, Reid ME, Iverson NR, LaHusen RG, Logan M, Mann JE, Brien DL (2000) Acute sensitivity of landslide rates to initial soil porosity. Science 290:513-516

Johnson AM, Rodine JR (1984) Debris flow. In: Brunsden D, Prior DB (eds) Slope Instability. Wiley, Chichester, pp 257-361

Kramer KL (1988) Triggering of liquefaction flow slides in coastal soil deposits. Eng Geol 26:17-31

Krumbein WC (1940) Flood gravel of San Gabriel Canyon, California. Geol Soc Am Bull 51:639-676

Krumbein WC (1942) Flood deposits of Arroyo Seco, Los Angeles County, California. Geol Soc Am Bull 53:1355-1402

Logan M, Iverson RM (2007 revised 2009), Video documentation of experiments at the USGS debris-flow flume 1992-2006 (amended to include 2007-2009): U.S. Geological Survey Open-File Report 2007-1315 v. 1.1 http://pubs.usgs.gov/of/ 2007/1315/.

Moore PL, Iverson NR (2002) Slow episodic shear of granular materials regulated by dilatant strengthening. Geology 30:843-846

Moriwaki H, Inokuchi T, Hattanji T, Sassa K, Ochiai H, Wang G (2004) Failure processes in a full-scale landslide experiment using a rainfall simulator. Landslides 1:277-288

Niem AR, Niem WA (1990) Geology and oil, gas, and coal resources, southern Tyee Basin, southern Coast Range, Oregon: Oregon Department of Geology and Mineral Industries, Open-File Report 0-89-3, 11 tables, 3 plates, $44 \mathrm{p}$

Poulos SJ, Castro G, France JW (1985) Liquefaction evaluation procedure. J Geotech Engineering 111:772-792

Reid ME, Iverson RM, LaHusen RG, Brien DL, Logan M (2008) Deciphering landslide behavior using large-scale flume experiments: In: Sassa, D, Canuti P (eds) Proceedings of The First World Landslide Forum, Parallel Sessions Volume, First World Landslide Forum, November 18-21, 2008, Tokyo, Japan

Reneau SL, Dietrich WE (1987) The importance of hollows in debris-flow studies; example from Marin County, California. In: Costa JE, Wieczorek GE (eds) Debris-flows/ Avalanches: Process, recognition, and mitigation, vol 7, Reviews in Engineering Geology. Geological Society of America, Boulder, pp 165-180

Rodine JD, Johnson AM (1976) The ability of debris heavily freighted with coarse clastic materials to flow on gentle slopes. Sedimentology 23:213-224

Rood KM (1990) Site Characteristics and Landsliding in Forested and Clearcut Terrain, Queen Charlotte Islands, BC. Land Management Report No. 64. British Columbia Ministry of Forests, Victoria, p 46

Roscoe KH, Schofield AN, Wroth CP (1958) On the Yielding of Soils. Geotechnique 8:2253

Rudnicki JW (1984) Effects of dilatant hardening on the development of concentrated shear deformation in fissured rock masses. J Geophys Res 89(B11):9259-9270
Sassa K (1984) The mechanism starting liquefied landslides and debris flows, Proceedings of the $4^{\text {th }}$ International Symposium on. Landslides 2:349-354

Schofield AN, Wroth CP (1968) Critical state soil mechanics. McGraw-Hill, New York, p 310

Schulz WH, Coe JA, Ellis WL, Kibler JD (2006) Preliminary assessment of landslides along the Florida River downstream from Lemon Reservoir, La Plata County, Colorado: U.S. Geological Survey Open-File Report 2006-1343, 29 p., 1 plate, map scale 1:2,770

Sharp RP, Nobles LH (1953) Mudflow of 1941 at Wrightwood, southern California. Geol Soc Am Bull 64:547-560

Smith TC, Hart EW (1982) Landslides and related storm damage, January 1982, San Francisco Bay region: California. Geology 35:139-152

Troxell HC, Peterson JQ (1937) Flood in La Canada Valley, California. U S Geol Surv Water Supp Paper 757C:53-98

Wang G, Sassa K (2003) Pore-pressure generation and movement of rainfall-induced landslides: Effect of grain size and fine-particle content. Eng Geol 69:109-125

Wiley TJ (2000) Relationship between rainfall and debris flows in western Oregon. Or Geol 62(2):27-43

J. P. McKenna (•)

U.S. Geological Survey,

Box 25046, MS-966, Denver, C0 80225, USA

e-mail: jmckenna@microseismic.com

\section{P. M. Santi}

Department of Geology and Geological Engineering,

Colorado School of Mines,

Golden, C0 80401, USA

\section{Amblard}

Ecole Polytechnique Universitaire Pierre et Marie Curie,

de I'Université Paris VI, Scences de la Terre,

Tour 56-66-2éme étage, case 95, 4 Place Jussieu, 75232 Paris, France

J. Negri

University of Michigan,

Flint, MI 48502, USA

Present Address:

J. P. McKenna

MicroSeismic, Inc.,

$62117^{\text {th }}$ St., Suite 2000, Denver, CO 80209, USA 